\title{
The difference of blood pressure before and after consuming Green Kiwi (Actinidia deliciosa) in the young adult group
}

\author{
Dian Lesmana*, Ervin Rizali*, Silvi Kintawati* \\ *Department of Oral Biology Faculty Of Dentistry Universitas Padjadjaran, \\ Indonesia
}

\begin{abstract}
Introduction: Green Kiwi fruit (Actinidia deliciosa) has a lot of nutritional content, one of them is potassium. Potassium helps maintain osmotic pressure in intracellular fluid, protect body's electrolyte balance, regulate heartbeat, maintain muscle and nerve cell function, reduce the risk of stroke and heart disesase, and decrease blood pressure. Methods: This study is an experimental research, using pair t-test measurement to analize the difference of blood pressure before and after consuming Green Kiwi fruit (Actinidia deliciosa) in early adulthod. The sample are thirty five students of Faculty of Dentistry, Padjadjaran. The number of green kiwi fruit is consume as much as 1 fruits or 150 grams. Blood pressure measured by sphygmomanometer with auscultatory-palpation method. Results: The result of this study shows the averaged blood pressure before and after consuming green kiwi fruit Is $99,543 / 68,438 \mathrm{mmHg}$ and $97,581 / 66,743 \mathrm{mmHg}$. Conclusion: The conclusion of the study indicates the existence of difference in blood pressure before and after consuming Green Kiwi fruit (Actinidia deliciosa) in early adulthood $(p<5 \%)$.
\end{abstract}

Keywords: Green Kiwi fruit, potassium, blood pressure.

\section{INTRODUCTION}

Health is a basic human need because health is very prime needed for life processes so that humans can grow, develop, and carry out their activities. All humans have experienced health conditions that are not so good. This poor health condition is caused by unhealthy eating patterns. The development of the era make everyone competing to follow it to the lifestyle and diet.

Changes in the modernization lifestyle, especially in big cities cause a decline in public health due to consuming fatty foods, using chemicals, or over-processed can cause the frequency of cardiovascular disease continues to increase. The pattern of human life in the position of frequent sitting, smoking habits, drinking alcoholic beverages, sleeping late at night, lack of exercise, severe stress, excessive sodium intake, eating less fruits and vegetables, and obesity also affect the high factor of individuals affected by heart attacks. ${ }^{1}$

Survey conducted by the Ministry of Health of the Republic of Indonesia on community 2 shows that cardiovascular disease has ranked first. ${ }^{2}$ High blood pressure is one of the most influential risk factors as a cause of cardiovascular disease affecting more than 800 million people

Corresponding author: Ervin Rizali, Department of Oral Biology, Faculty of Dentistry Universitas Padjadjaran, Indonesia. Jalan Sekeloa Selatan I, Bandung, West Java, Indonesia, 40132; Phone: +6222-2504985/2532805 
worldwide. Approximately 10-30 percent of the adult population in almost all countries experience high blood pressure. About 50-60 percent of the adult population can be categorized as a major majority, whose health status will be better if blood pressure can be controlled. ${ }^{3}$

High blood pressure is an increase in blood pressure in the arteries. Arteries are blood vessels that carry blood from the heart and are distributed to all tissues and organs of the body. High blood pressure does not mean excessive emotions, although emotions and stress can increase blood pressure for a while. ${ }^{4}$ In general, high blood pressure is a condition without symptoms, namely high blood pressure in the arteries that causes an increased risk of heart disease (cardiac), kidney disease (renal), hardening of the arteries (atherosclerosis/arteriosclerosis), eye damage, aneurysm, and stroke (brain damage).

High blood pressure occurs if when seated systolic pressure reaches $140 \mathrm{mmHg}$ or more, or diastolic pressure reaches $90 \mathrm{mmHg}$ or more, or both. In high blood pressure, usually an increase in systolic and diastolic pressure. Blood pressure in a person's life varies naturally. Infants and children normally have blood pressure that is much lower than adults. Blood pressure is also influenced by physical activity that will be higher when doing activities and lower when resting. ${ }^{4}$

Broadly speaking high blood pressure treatment is divided into two categories: nonpharmacological treatment and pharmacological treatment. Nonpharmacologic treatment is treatment without drugs that are applied to high blood pressure. In this way, blood pressure reduction is pursued through prevention by living a healthy lifestyle and the use of natural ingredients. Pharmacological treatment is a treatment that uses modern medicines. Pharmacological treatment is performed on patients with high blood pressure with the blood pressure of $140 / 90 \mathrm{mmHg}$ or more. ${ }^{5}$

Treatment using modern medicines has side effects for the patient's body, so the basic strategy of pharmacological treatment is to choose small doses that are effective for avoiding side effects. This is very important because most people with high blood pressure cannot be completely cured and have to take these drugs for life. Termination of a few days will increase blood pressure again. ${ }^{3}$ Therefore, pharmacological treatment is usually done with modern medicines. ${ }^{5}$

Indonesia as a tropical country is famous for its variant flora. Approximately 30,000 types of plants can be found and are widely distributed throughout Indonesia. Some of them can be used to maintain the health of the body, such as green kiwifruit (Actinidia deliciosa) which can be used as a blood pressure reducer. Kiwi is known as the biggest vitamin C-producing fruit among other fruits. Vitamins in kiwi are also very diverse.

The content of vitamin $C$ in the kiwi is 17 times more than apples. Kiwi also contains vitamins $\mathrm{E}, \mathrm{B} 1, \mathrm{~B} 2, \mathrm{~B} 6$, and vitamin $\mathrm{A}$. The role of vitamins $C$ and $E$ in kiwi as antioxidants, free radicals that cause premature aging and prevent cancer cells. The high content of vitamin $\mathrm{C}$ in kiwi makes this fruit can be used to reduce high blood pressure. ${ }^{6,7}$

Research conducted by Dr. Paul La Chence (1997), this imported fruit is proven to be beneficial for health. The results of his research show that kiwi is a fruit that has the highest nutrient density compared to other fruits and contains vitamin $\mathrm{E}$ as an antioxidant and is needed for heart health, folic acid to prevent defects in infants, both for brain development, and prevent disease cardiovascular, and potassium to maintain the condition of blood pressure and heart health. ${ }^{7}$

Based on information in the background of the study, the authors are interested in knowing the differences in blood pressure before and after consuming green kiwifruit (Actinidia deliciosa) in young adult groups. The study aimed to obtain data on differences in blood pressure before and after consuming green kiwifruit (Actinidia deliciosa) in the young adult group.

\section{METHODS}

This type of research is experimental by measuring systolic and diastolic blood pressure before and after consuming green kiwifruit (Actinidia deliciosa) in a group of young adults in Bandung in 2011. The population of this research is the students of the Faculty of Dentistry, Padjadjaran University, Bandung, who are in the young adult age group. The number of samples in this study were 35 people by means of purposive sampling with several criteria for ages 20-26 years, general health is good and not suffering from systemic 
abnormalities, not taking drugs that affect blood pressure, non-smokers, as long as the study does not consume alcoholic beverages and coffee, is willing to be a respondent of research, as long as the study does not carry out strenuous activities. ${ }^{8,9}$

\section{RESULTS}

This research was conducted on 35 respondents who met the criteria by measuring blood pressure (systolic and diastolic) before and after consuming green kiwifruit (Actinidia deliciosa) in young adult groups. The results of measuring the difference in average blood pressure before and after consuming green kiwifruit (Actinidia deliciosa) can be seen in Appendix 5 and 6, while the results of statistical calculations and hypothesis testing can be seen in Appendix 7. The mean blood pressure of respondent before and after consuming green kiwifruit (Actinidia deliciosa) is presented in Table 1., while the statistical analysis is presented in Table 2. Table 2 .

Indicate the average value of systolic pressure before and after consuming green kiwi fruit (Actinidia deliciosa) amounting to 1.962 $\mathrm{mmHg}$ with standard deviation 2.536 and based on statistical analysis obtained T count by 4.577 . After obtaining an average blood pressure before and after consuming green kiwifruit (Actinidia deliciosa), it can be found the difference in

Table 1. Average Blood Pressure Before and After Consuming Green Kiwifruit (Actinidia deliciosa)

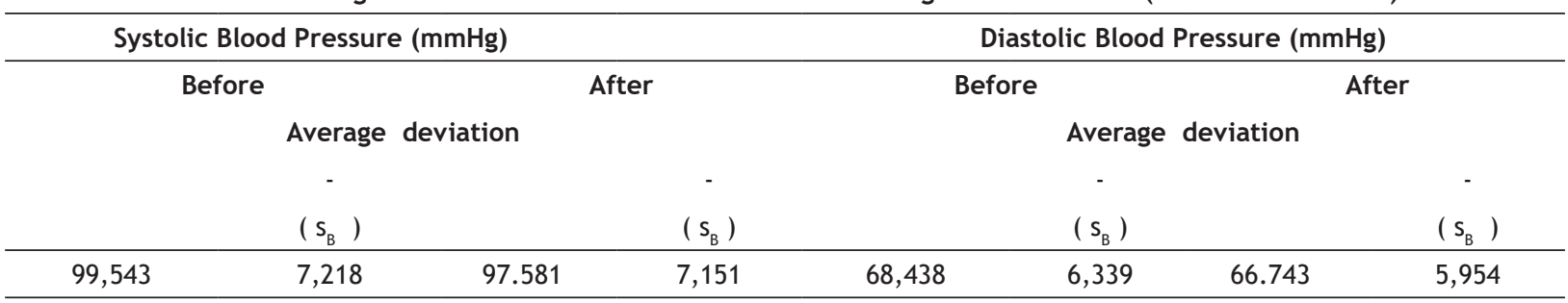

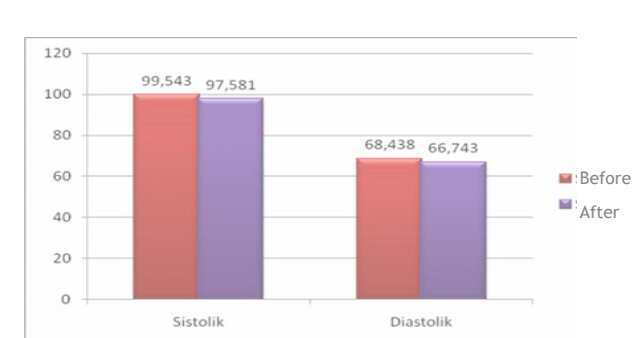

Figure 1. Average Blood Pressure Before and After Consuming Green Kiwifruit (Actinidia deliciosa)

average values, the standard deviation difference, and $\mathrm{t}$ calculate blood pressure before and after consuming green kiwifruit (Actinidia deliciosa). The results of these calculations can be seen in Table 2.

The average difference in the value of diastolic pressure before and after consuming green kiwi fruit (Actinidia deliciosa) amounted to $1.695 \mathrm{mmHg}$ with a standard deviation of 2.153 and based on the statistical analysis acquired $T$ count by 4.658 . The results of the research obtained are calculated statistically using the data test method in pairs.

Data Paired Test for systolic blood pressure. Reject Ho If $T$ counts the table $\geq T$. Thank Ho in other respects. $T$ count $=4.577>\mathrm{T}$ table $=2.032$. With a significance rate of $5 \%$, there is a difference
Table 2. Difference in Mean Values of Blood Pressure Before and After Consuming Green Kiwifruit

\begin{tabular}{cccc}
\hline Measurement & Average & $\begin{array}{c}\text { Standard } \\
\text { deviation }\end{array}$ & $\mathrm{t}$ \\
\hline & Difference & & count \\
\hline $\begin{array}{c}\text { Systolic blood pressure } \\
\text { (mmHg) }\end{array}$ & 1,962 & 2,536 & 4,577 \\
\hline $\begin{array}{c}\text { Diastolic blood pressure } \\
\text { (mmHg) }\end{array}$ & 1,695 & 2,153 & 4,658 \\
\hline
\end{tabular}

in the average systolic blood pressure before and after consuming green kiwi fruit (Actinidia deliciosa) in young adult groups. Test the paired Data for diastolic blood pressure. Reject Ho If $T$ counts the table $\geq \mathrm{T}$. Thank Ho in other respects. T count $=4.658>\mathrm{T}$ table $=2.032$. In conclusion, with a significance of $5 \%$, there is a difference in the average diastolic blood pressure before and after consuming green kiwi fruit (Actinidia deliciosa) in young adult groups.

\section{DISCUSSION}

Based on the results of research that has been done there is a difference in blood pressure before and after consuming green kiwi fruit (Actinidia deliciosa) in young adult groups. Systolic and 
diastolic blood pressure after consuming green kiwi fruit (Actinidia deliciosa) decreased. Decreased systolic blood pressure after consuming green kiwi fruit (Actinidia deliciosa) from an average of $99.543 \mathrm{mmHg}$ to $97.581 \mathrm{mmHg}$ and decreased diastolic pressure from an average of $68.438 \mathrm{mmHg}$ to $66.743 \mathrm{mmHg}$.

Kiwi fruit consumption is recommended for people with high blood pressure to prevent stroke and heart attack because kiwifruit contains potassium that affects blood pressure. Potassium content in kiwi fruit is instrumental in regulating the heart rate to remain normal, lowering blood pressure, and blood circulation. ${ }^{7}$

Potassium works alongside sodium, but the working mechanism of potassium is the opposite of sodium. Sodium is found in the extracellular fluid in the body. ${ }^{10}$ The excessive consumption of sodium causes sodium concentration in the extracellular fluid increases, to normalized it, intracellular fluid is pulled out so that Increased extracellular fluid volume. Increasing the volume of the extracellular fluid caused increased blood volume, resulting in high blood pressure. ${ }^{11}$

Potassium is found in intracellular fluid. ${ }^{10}$ potassium plays a role in regulating osmotic pressure in intracellular fluid, maintaining the body's electrolyte balance, regulating heart rate, maintaining the function of muscles and nerve cells, lowering the risk of stroke and heart disease. ${ }^{2}$ consumption of potassium will increase its concentration in an intracellular fluid so that it will draw fluid from the extracellular part and lower blood pressure. ${ }^{1}$

Potassium ratio and unbalanced sodium can affect blood pressure. Excessive consumption of sodium chloride (kitchen salt) is excessively accompanied by the lack of potassium intake can cause high blood disease. This is due to sodium ions that can cause water retention so that the volume of fluid in the body increases and causes an increase in blood pressure. ${ }^{12}$

High potassium content in kiwi fruit also serves as a diuretic. The diuretic mechanism is the most commonly used mechanism for treating high blood pressure. This mechanism removes excess sodium and water in the form of urine through the excretion of the kidneys thereby lowering the volume in blood circulation, increasing the dilation of blood vessels and reducing the pressure in the walls of blood vessels. ${ }^{1}$

In the treatment of high blood pressure, diuretics decreased volume in blood circulation and increased blood vessel dilation. ${ }^{13}$ In this study was sampled respondents aged between 20-26 years which are physiological in the optimal phase so that blood pressure can be controlled by the physiological reflex of the cardiovascular system. ${ }^{14}$

The results of the study expressed a decrease in blood pressure after consuming green kiwi fruit (Actinidia deliciosa) in young adult groups. This is by the theory previously stated. Kiwi fruit consumption is recommended for people with high blood pressure to prevent stroke and heart attack because kiwifruit contains potassium that affects blood pressure. ${ }^{7}$

\section{REFERENCES}

1. Beevers DG. Tekanan Darah. Diterjemahkan dari Blood Pressure. Oleh: Diana Susyanti. Jakarta: Dian Rakyat. 2002. 28-45, 55-59.

2. Suharjo JB, Cahyono. Gaya Hidup dan Penyakit Modern. Yogyakarta: Kanisius. 2008. 25.

3. Indriyani WN. Deteksi Dini Kolesterol, Hipertensi dan Stroke. Milestone. 2009. 3790.

4. Abidin. Definisi Tekanan Darah Tinggi (Hipertensi). 2009. Available at: http:// abidinblog.blogspot.com/2009/10/ hipertensi-tekanan-darah-tinggi.html (diakses 18 Februari 2011).

5. Junaidi I. Hipertensi. Jakarta: Bhuana IImu Populer. 2010;16(29):35-36.

6. Astawan M, Kiwi. Si Eksotik Paling Padat Nutrisi. 2008. Available at: http://nasional. kompas.com/read/2008/12/27/0958276/ kiwi.si.eksotik.paling.p adat.nutrisi (diakses 18 Februari 2011).

7. Pangkalan Ide. Health Secret of Kiwifruit. Jakarta: ElexMedia Komputindo. 2010. 6-23, 32-40, 66-72, 75-77, 135-137.

8. Sudjana. Metoda Statistika. Bandung: Tarsito: 1989. 168-169.

9. Notoatmojo S. Metodologi Penelitian Kesehatan. Jakarta: Rineka Cipta. 2002.138144.

10. Sediaoetama AD. Ilmu Gizi jilid I. Jakrta: Dian Rakyat. 2000. 170-175.

11. Astawan M. Cegah Hipertensi dengan Pola 
Makan. 2003.

12. Lovastatin K. Penyakit Jantung dan Tekanan Darah Tinggi. Jakarta : Prestasi Pustaka. 2006. 69-79.

13. Lilly LS. Pathophysiology of Hearth Disease 4 th ed. Philadelphia: Lippincott Williams and
Wilkins. 2007.431.

14. Guyton AC, Hal JE. Buku Ajar Fisiologi Kedokteran Edisi 9. Diterjemahkan dari Textbook of Medical Physiology, 9th ed. Oleh Irawati Setiawan. Jakarta : EGC. 1997. 205215. 